\title{
Relative Palatability of Seven Artemisia Taxa to Mule Deer and Sheep
}

\author{
DENNIS P. SHEEHY AND A.H. WINWARD
}

\begin{abstract}
Relative preference for seven important sagebrush taxa in Oregon was established for mule deer and domestic sheep. Mule deer showed highest preference for low sagebrush (A rtemisia arbuscula ssp. arbuscula), mountain big sagebrush $(A$. tridentata ssp. vaseyana), foothill big sagebrush (a recently recognized variant of mountain big sagebrush) and Bolander silver sagebrush $(A$. cana ssp. bolanderi). They showed intermediate preference for basin big sagebrush ( $A$. tridentata ssp. tridentata) and Wyoming big sagebrush ( $A$. tridentata ssp. wyomingensis) and least preference for black sagebrush (A. nova). Sheep showed highest preference for low sagebrush and medium preference for black sagebrush. They utilized but did not prefer, Bolander silver sagebrush and mountain and foothill big sagebrush and they showed least preference for Wyoming and basin big sagebrush. Genetic variation between kinds of sagebrush taxa influenced animal preference more than environmental variation within a taxon.
\end{abstract}

Although many articles have been written regarding utilization of sagebrush by both native and domestic animals, confusion still exists regarding which sagebrush taxa are preferred by animal consumers.

Two trends in sagebrush utilization by deer are evident in the literature: (1) Heaviest use occurs during the winter months, (2) Taxa most often mentioned include big sagebrush ( $A$. tridentata) and low sagebrush (A. arbuscula) (Smith 1950, Kufeld et al. 1973).

Likewise with sheep, most utilization takes place during the winter season. Big sagebrush and black sagebrush $(A$. nova $)$ are the two taxa most often associated with sheep use.

Most past research involving utilization of sagebrush has been based on recognition at the generic or, at best species level. A considerable amount of recent literature has shown that species, subspecies, and forms exist, each with their own morphological characteristics and environmental requirements (Beetle 1960; Beetle and Young 1965; Tisdale et al. 1969; Winward and Tisdale 1977; Hanks et al. 1971; Brunner 1972; Hanks et al. 1973, McArthuret al. 1979). Only a few researchers have studied sagebrush utilization at the subspecies and form level under controlled or semicontrolled experimentation (Hanks et al. 1971; Hanks et al. 1973; and Scholl et al. 1977).

The purpose of this study was to evaluate relative animal preference for seven important sagebrush taxa in Oregon under conditions where all seven taxa were available for selection. The seven taxa studied included: (1) Artemisia arbuscula Nutt. ssp. arbuscula-low sagebrush (Lo), (2) A. cana ssp. bolanderi (Gray) Ward-Bolander silver sagebrush (Bo), (3) A. nova Nelson-black sagebrush (B1), (4) A. tridentata ssp. tridentata Nutt.-basin big sagebrush (Ba), (5) A. tridentata ssp. vaseyana (Rydb.) Beetlemountain big sagebrush (Mo), (6) $A$. tridentata ssp. wyomingensis Beetle-Wyoming big sagebrush (Wy) and (7) a relatively low

\footnotetext{
Authors are former graduate research assistant and associatc professor, Rangcland Resources Program, Oregon State University, Corvallis, respectively. Mr. Sheehy is presently a rancher in Wallowa, Oregon, and Dr. Winward is regional ecologist for the US Forest Service, Intermountain Region, Ogden, Utah.

This article was submitted as Technical Paper No. 5392. Oregon Agricultural Experiment Station, Corvallis.

Manuscript received January 28, 1980
}

elevational variant of $A$. tridentata ssp. vaseyana referred to in this paper as foothill big sagebrush (Fo). Nomenclature follows Beetle (1960) and Beetle and Young (1965) except for the last taxon which was encountered in Oregon but at the present time is not an officially recognized subspecies.

\section{Procedures}

Since it was not possible to find all seven taxa growing together in a confined field situation, plants were collected live from three geographic areas of the state and brought to a centralized location for study. These areas were: (1) the general vicinity of Silver Lake, Oregon, (2) on or near the Squaw Butte experimental range near Burns, Oregon, and (3) in the vicinity of Baker, Oregon. Plants were selected from these three separate geographic areas to test for selectivity differences which might result from environmental features associated with each site. Collections were made in the fall, 1973, and plants were kept in the same soil found around their roots in the field as a means of minimizing transplanting influences. A total of 476 individual plants were collected.

Rocky mountain mule deer (Odocoileus hemionus ssp. hemionus Rafinesque) used in the deer selectivity trials were wild trapped from the Steen's Mountain winter range in eastern Oregon through the cooperation of the Oregon Department of fish and Wildlife. The mule deer were maintained for the duration of the selectivity trials by allowing them free access to grain and alfalfa pellets and alfalfa hay. Three mule deer selectivity trials (two in winter and one the following fall) with four deer used in each trial were conducted in 1974. Five sagebrush plants of each taxon from the three collection locations were used for a total of 105 plants in each trial.

Columbia type eastern Oregon range ewes were obtained from the Animal Science Department at Oregon State University for the sheep selectivity trials. The ewes were allowed free access to pasture before and after utilization periods in each selectivity trial. Four selectivity trials (three in winter and one the next fall) with four ewes in each trial were conducted in 1974. Three plants of each taxon from the three collection locations were used for a total of 63 plants in each trial. Some plants used in the winter trials which initiated adequate regrowth during the spring and summer seasons were reused in the following fall trials.

Utilization of current year's growth on each sagebrush plant was calculated by measuring leader growth (with leaves) on a marked portion of each plant prior to the beginning of each trial, followed by subsequent measurements at three designated intervals during the trial. Designated utilization intervals (use periods) for the mule deer were 2 hours, 20 hours, and 48 hours during the winter trials and 1 hour, 12 hours, and 24 hours in the following fall trial. Designated utilization intervals for the ewes were 24 hours for the first interval and 48 hours for both the second and third intervals in both the winter and fall selectivity trials.

Percent composition of growth available on each kind of sagebrush at the beginning of a selectivity trial was calculated by multiplying oven-dry weight values of current year's growth from representative weighed leaders by the total number of leaders on each sagebrush plant. Percent utilization was determined during 
each use period by evaluating before and after measurements as described by Cassady (1941). Percent utilization and composition values were then used to compute Relative Preference Indices (RPI) for the seven taxa in each trial with the following formula:

$$
\mathrm{RPI}=\frac{\% \text { diet }(\text { based on utilization) }}{\% \text { composition available }}
$$

(Van Dyne and Heady 1965). All statistical tests were made at $P<0.05$.

\section{Results}

Mule deer and sheep showed a considerable difference in their reaction to the sagebrush plants. Following an initial period of adjustment to inclusion of the potted plants within the pen area, the mule deer selected readily from among the sagebrush taxa (Fig. 1). Sheep, however, showed less inclination to utilize the sagebrush and had to be induced to select from among the taxa by removal of other food sources. Within a few hours both deer and sheep appeared to have developed preferences for certain taxa. As they encountered pots containing taxa they preferred, they spent longer periods browsing these plants, but did utilize some growth from nearly all plants in each trail.

During the winter trials it became apparent that growth form of some taxa had an influence on availability of current year's growth. Species such as low sagebrush and black sagebrush, which have a high portion of their growth intermixed with woody branches, could not be browsed as readily as those species with more open crowns. Since utilization was computed as a percent of growth remaining after each trial, availability of plant material highly influenced evaluation of animal selectivity. For this reason all current year's growth was made available to animals in the following fall trials by hand clipping and removing any unavailable leaves and branches prior to the trials.

Only the first and second use periods were evaluated for both classes of a nimals since by the third use period, almost all available growth had been utilized from plants in the trials. In the final analysis the first use period of the winter trials and the second use period of the subsequent fall trials were selected for evaluating both deer and sheep preference. During these time periods the animals had ample time to select freely from all plants in the trials, yet some growth was available on lesser preferred plants at the end of the time period.

Relative preference values for both the two winter deer trials and the three winter sheep trials were pooled for each class of a nimal. It was felt that pooling the results of each set of trials would remove or reduce the potential bias that might exist between trials since different groups of deer or sheep were used in each trial. A complete discussion of all trials and use periods is available in Sheehy (1975).

Pooled data from the winter trials indicated that deer preferred foothill and mountain big sagebrush and Bolander silver sagebrush

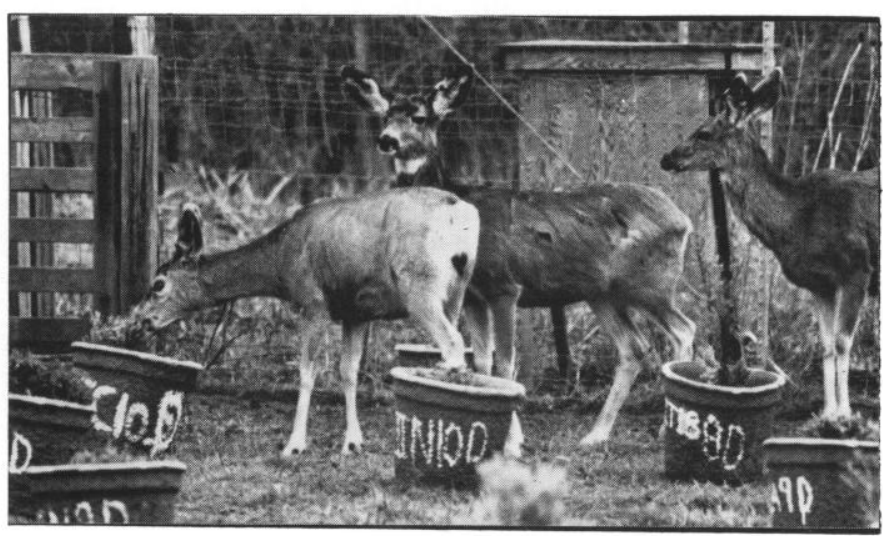

Fig. 1. Mule deer selectively browsing individual sagebrush taxa.
(Table 1). They showed moderate preference for low sagebrush and Wyoming and basin big sagebrush and least preference for black sagebrush. Data from the following fall trial indicated that low sagebrush, mountain and foothill big sagebrush and Bolander silver sagebrush were most highly preferred. Deer utilized, but did not prefer, basin big sagebrush and they showed least preference for Wyoming big sagebrush and black sagebrush.

Table 1. Relative preference index for seven sagebrush taxa to mule deer and sheep in Oregon.

\begin{tabular}{|c|c|c|c|c|c|c|c|}
\hline Season & & & $\operatorname{Pr}$ & erenc & Index & & \\
\hline & & & & De & & & \\
\hline Winter trials (pooled) & Fol ${ }^{1}$ & Mo & Bo & Lo & Wy & $\mathrm{Ba}$ & $\mathrm{Bl}$ \\
\hline Use Period 1 & $1.6^{\mathrm{a} 2}$ & $1.4^{\mathrm{a}}$ & $1.3^{\mathrm{a}}$ & $0.8^{\mathrm{b}}$ & $0.8^{\mathrm{b}}$ & $0.5^{\mathrm{b}}$ & $0.0^{\circ}$ \\
\hline Fall trial & Lo & Mo & Fo & Bo & $\mathrm{Ba}$ & Wy & $\mathrm{Bl}$ \\
\hline Use Period 2 & $1.9^{\mathrm{a}}$ & $1.6^{\mathrm{a}}$ & $1.5^{\mathrm{a}}$ & $1.5^{\mathrm{a}}$ & $0.4^{\mathrm{a}}$ & $0.2^{c}$ & $0.1^{\mathrm{c}}$ \\
\hline & & & & She & & & \\
\hline Winter trials (pooled) & Lo & Bo & Fo & $\bar{M}_{0}$ & $\mathrm{Bl}$ & Wy & $\mathrm{Ba}$ \\
\hline Use Period 1 & $1.6^{\mathrm{a}}$ & $1.6^{\mathrm{a}}$ & $1.4^{\mathrm{a}}$ & $1.1^{\mathrm{ab}}$ & $0.6^{b c}$ & $0.5^{\mathrm{c}}$ & $0.5^{c}$ \\
\hline Fall trial & Lo & $\mathrm{Bl}$ & Bo & Mo & Fo & Wy & $\mathrm{Ba}$ \\
\hline Use Period 2 & $5.2^{\mathrm{a}}$ & $2.3^{\mathrm{b}}$ & $1.3^{\mathrm{bc}}$ & $1.0^{\mathrm{bc}}$ & $0.8^{b c}$ & $0.0^{\mathrm{c}}$ & $0.0^{c}$ \\
\hline
\end{tabular}

${ }^{1} \mathrm{Ba}=$ basin big sagebrush; $\mathrm{Bl}=$ black sagebrush; $\mathrm{Bo}=$ Bolander silver sagebrush; $\mathrm{Fo}=$ foothill big sagebrush; Lo=low sagebrush; Mo=mountain big sagebrush; Wy $=$ Wyoming big sagebrush.

2Index values followed by the same letter were not significantly different at the 0.05 level according to Duncan's multiple range test.

The major difference in the fall trial was high utilization of sagebrush. This was probably related to the proportional increase in availability of current year's growth on these plants as a result of hand clipping unavailable herbage. Since utilization of black sagebrush, which is similar in growth form to low sagebrush, remained relatively low in this trial, the increase in utilization of low sagebrush indicated availability was a major factor influencing higher utilization of this taxon in the fall trial. Also, mountain and foothill big sagebrush and Bolander silver sagebrush were as highly utilized in the fall trial as they were in the winter trials yet utilization of basin and Wyoming big sagebrush and black sagebrush remained low.

In winter trials sheep preferred low sagebrush, Bolander silver sagebrush and foothill and mountain big sagebrush (Table 1). They showed moderate preference for black sagebrush and Wyoming and basin big sagebrush. During the fall trial in which all growth was made available through clipping, the Relative Preference Index for low and black sagebrush was considerably higher. In this trial sheep preferred low sagebrush by a wide margin over other taxa but readily utilized black sagebrush. Bolander silver sagebrush and mountain and foothill big sagebrush were selected next with Wyoming and basin big sagebrush least preferred.

Mule deer and sheep preference for the seven sagebrush taxa appeared to be affected very little by differences related to collection area. No consistent trends were recognizable from statistical analysis of utilization values compared by area of collection (Sheehy 1975). Selection by animals was, therefore, believed to be related primarily to genetic variation between the sagebrush taxa.

\section{Discussion}

Results of studies by several other authors generally agree with the relative placement of these taxa into palatability groups. Scholl et al. (1977) and Welch and McArthur (1979) found mountain big sagebrush to be relatively more palatable than basin or Wyoming big sagebrush. Scholl et al. (1977) also found low sagebrush to be among the more preferred sagebrush taxa. No studies could be found which showed a measured relative preference for Bolander silver sagebrush. Scholl et al. (1977) indicated that mountain silver sagebrush (A. cana ssp. viscidula) was moderately palatable to mule deer.

A considerable amount of variation exists in the literature concerning the relative palatability of black sagebrush. Dietz and 
Nagy (1976) observed black sagebrush to be more highly selected by mule deer than big sagebrush but no direct use data were shown to support their observations. Smith's (1950) work, however, agreed with our finding of a low palatability of black sagebrush to deer. Since there are two known color variations of black sagebrush (Winward and Tisdale 1969 and Stevens and McArthur 1974) differences in palatability among studies may be related to genetic variability within this species.

Although this study was conducted in an "artificial" setting, i.e., (1) plant species were grouped together even though they are not normally found together in the field and (2) the trials were held in an unnatural environment, animal preference for the sagebrush taxa was essentially the same regardless of collection area or season of the year in which the trials were held. Therefore, the judgements relative to management of sagebrush as forages in their natural environments are appropriate.

Some of the important factors which should be considered as a result of this study include:

(1) Both deer and sheep selected sagebrush at taxonomic levels finer than the species ranking. Consequently, it is important that we recognize sagebrush at the subspecies and form levels.

(2) Factors which determine acceptability of a particular taxon are apparently genetically fixed and may have only slight modification by the environment.

(3) Literature which presents high palatability ratings for a particular sagebrush taxon should be considered in light of which other sagebrush taxa and what other plant species were available for use. High palatability of sagebrush taxa in relation to other taxa does not necessarily suggest they will have high palatability in relation to other kinds of forage or that sagebrush is a good source of nutrients.

(4) Programs directed toward management of sagebrush should consider as an additional factor, the relative palatability of the taxon or taxa involved.

(5) On areas where sagebrush seeding or planting programs are contemplated for game range improvement, consideration should be given to the relative palatability of species which are adapted to the particular site.

(6) A considerable amount of research should be directed towards selection and crossing of sagebrush taxa which would favor both their palatability and their tolerances to the environment of specific range sites.

\section{Conclusions}

In general, mule deer showed highest preference for low sagebrush, mountain and foothill big sagebrush, and Bolander silver sagebrush. They showed intermediate preference for basin and Wyoming big sagebrush and least preference for black sagebrush.

Sheep showed highest preference for low sagebrush and medium preference for black sagebrush. They utilized but did not prefer Bolander silver sagebrush and mountain and foothill big sagebrush and they showed least preference for Wyoming and basin big sagebrush.
Differences in animal selection within taxa collected from different geographic areas showed no consistent pattern. Genetic variation between kinds of sagebrush appeared to be the major feature influencing utilization of these taxa.

\section{Literature Cited}

Beetle, A.A. 1960. A study of sagebrush. The section Tridentatae of Artemisia. Wyoming Agr. Exp. Sta. Bull. 368.83 p.

Beetle, A.A., and A. Young. 1965. A third subspecies of the Artemisia tridentata complex. Rhodora 67:405-406.

Brunner, J.R. 1972. Observations on Artemisia in Nevada. I. Range Manage. 25:205-208.

Cassady, J.R. 1941. A method of determining range forage utilization by sheep. J. Forest. 39:666-671.

Dietz, D.R., and J.G. Nagy. 1976. Mule deer nutrition and plant utilization. In: Mule deer decline in the West-A Symposium. G.W. Workman and J.B. Low (eds.) Coll. Natur. Resour., Utah Agr. Exp. Sta. Logan, Utah. p. 71-78.

Hanks, D.L., J.R. Brunner, D.R. Christensen, and A.P. Plummer. 1971. Paper chromatography for determining palatability differences in various strains of big sagebrush. U.S. Dep. Agr. Intermountain Forest and Range Exp. Sta., Ogden, Utah, U.S. Forest Serv. Res. Pap. INT-101. 9 p.

Hanks, D.L., E.D. MacArthur, R. Stevens, and A.P. Plummer. 1973. Chromatographic characteristics and phylogenetic relationships of Artemisia, section tridentatae. U.S. Dep. Agr. Intermountain Forest and Range Exp. Sta., Ogden, Utah, U.S. Forest Serv. Res. Pap. INT-141. 24 p.

Kufeld, R.C., O.C. Wallmo, and C. Feddema. 1973. Foods of the Rocky Mountain mule deer. U.S. Dep. Agr. Forest Serv. Res. Pap. RM-111.31 p.

McArthur, E.D., A.C. Blauer, A.P. Plummer, and R. Stevens. 1979. Characteristics and hybridization of important intermountain shrubs. III. Sunflower family. Intermountain Forest and Range Exp. Sta., Ogden, Utah, U.S. Dep. Agr. Forest Serv. Res. Pap. INT-220. 82 p.

Scholl, J.P., P.G. Kelsey, and Fred Shafiyadeh. 1977. Involvement of volatile compounds of Artemisia in browse preference by mule deer. Biochem. Sys. and Ecol. 5:291-295.

Sheehy, D.P. 1975. Relative palatability of seven Artemisia taxa to mule deer and sheep. M.S. Thesis. Oregon State Univ., Corvallis. 147 p.

Stevens, Richard, and E. Durant McArthur. 1974. A simple field technique for identification of some sagebrush taxa. J. Range Manage. 27:325-326.

Tisdale, E.W., M. Hironaka, and M.A. Fosberg. 1969. The sagebrush region in Idaho, a problem in resource management. Univ. Idaho Agr. Exp. Sta. Bull. 512. 14 p.

Van Dyne, G.M., and H.F. Heady. 1965. Botanical composition of sheep and cattle diets on a mature annual range. Hilgardia 36:465-492.

Welch, Bruce L., and E. Durant McArthur. 1979. Feasibility of improving big sagebrush (Artemisia tridentata) for use on mule deer winter ranges. In: International Arid Lands Conference on Plant Resources. J.R. Goodin and D.K. Northington (eds.) Texas Tech. Univ., Lubbock, Texas. p. $451-473$.

Winward, A.H., and E.W. Tisdale. 1977. Taxonomy of the Artemisia tridentata complex in Idaho. Coll. of For., Wildl., and Range Sci., Univ. of Idaho, Moscow. Bull. 19. 15 p.

Winward, A.H., and E.W. Tisdale. 1969. A simplified chemical method of sagebrush identification. Univ. of Idaho, For., Wildl. and Range Exp. Sta. Note No. 11. 2 p. 